\title{
The Psychopharmacological Revolution in the USSR: Schizophrenia Treatment and the Thaw in Soviet Psychiatry, 1954-64
}

\author{
BENJAMIN ZAJICEK * \\ Towson University, 8000 York Road, Towson, MD 21252-0001, USA
}

\begin{abstract}
Twentieth-century psychiatry was transformed in the 1950s and 1960 s by the introduction of powerful psychopharmaceuticals, particularly Chlorpromazine (Thorazine). This paper examines the reception of Chlorpromazine in the Soviet Union and its effect on the Soviet practice of psychiatry. The drug, known in the USSR by the name Aminazine, was first used in Moscow in 1954 and was officially approved in 1955. I argue that Soviet psychiatrists initially embraced it because Aminazine enabled them to successfully challenge the Stalin-era dogma in their field (Ivan Pavlov's 'theory of higher nervous activity'). Unlike in the West, however, the new psychopharmaceuticals did not lead to deinstitutionalisation. I argue that the new drugs did not disrupt the existing Soviet system because, unlike the system in the West, the Soviets were already dedicated, at least in theory, to a model which paired psychiatric hospitals with community-based 'neuropsychiatric dispensaries.' Chlorpromazine gave this system a new lease on life, encouraging Soviet psychiatrists to more rapidly move patients from in-patient treatment to 'supporting' treatment in the community.
\end{abstract}

Keywords: History of Psychiatry, Soviet Union, Chlorpromazine, Aminazine, Psychopharmacology

In 1954, psychiatrists in Moscow began to give their patients Chlorpromazine, a promising new drug imported from France. By 1960, this drug, manufactured in the USSR under the name Aminazine, had become ubiquitous in Soviet psychiatric medicine, and its production and distribution had become a matter of crucial importance for patients and their families. Soviet researchers too found Aminazine useful. Not only did it open new possibilities for studying the physiology of mental illness, it provided them with a scientific justification for abandoning the narrow scientific dogmas of the late Stalin era. Within the discipline, demonstrating one's dedication to psychopharmocology became part of what

* Email address for correspondence: bzajicek@towson.edu

This article is based on research conducted with the support of a US Department of Education Fulbright-Hays Doctoral Dissertation Research Abroad Fellowship, with additional funds provided by the Towson University Academy of Scholars. An earlier version was presented at the conference Continuity and Change in Russian Therapy, held at St Antony's College, University of Oxford, 5-6 June 2014. The author would like to thank Fran Bernstein, Chris Burton, Daniel Todes and the anonymous referees for their helpful comments. 
it meant to demonstrate one's dedication to de-Stalinisation. Psychiatry was entering a new age, psychiatrists claimed. They were leaving behind old ideas, tired dogmas and failed treatments. Writing in 1961, the editor of The Korsakov Journal of Neuropathology and Psychiatry described the creation of these new drugs as 'no less important than synthesizing vitamins and antibiotics'.

The Soviet Union was not alone in this, of course. Chlorpromazine had a profound effect on psychiatry everywhere. Best known by the brand name Thorazine, it helped ameliorate the symptoms of psychosis: patients became calmer, hallucinations diminished, violent disturbance ceased. Researchers used Chlorpromazine and other 'neuroleptic' drugs to study the brain, developing new theories about the role of brain chemistry in mental illness, changing how both physicians and the public understood psychiatric disease. In the United States, reformers used Chlorpromazine to press for the deinstitutionalisation of psychiatric patients, resulting in the massive closure of psychiatric hospitals in the 1960s and 1970s. ${ }^{2}$

Historians of psychiatry have begun to study this mid-twentieth-century 'psychopharmacological revolution', examining how neuroleptics were integrated into clinical practice, how they changed psychiatric institutions and how they contributed to new ways of thinking about mental illness. ${ }^{3}$ The role of neuroleptics in psychiatric reform has been of particular interest. In some places, like the United States, deinstitutionalisation followed the introduction of neuroleptics, while in others, like France, neuroleptics were integrated into an existing system of psychiatric hospitals. Nicolas Henckes has argued that in order to understand these developments, historians must examine the specific contexts into which new psychiatric technologies were introduced and, in particular, the conditions that 'made given actors in given situations prone to endorse this project [of reform] and what made organisations, professional associations, commissions or parliamentary majorities become interested and willing to put it on their agenda'. By historicising the conditions in which psychiatric change took place, historians can move away from normative judgements about the success or failure of deinstitutionalisation. ${ }^{4}$

In the Soviet Union, the psychiatric health system and psychiatric profession were both highly centralised, with power held in the hands of a small group of psychiatrists and public health officials centred in Moscow. Psychiatry in the Soviet Union fell under the purview of the USSR Ministry of Health, a government agency which oversaw a countrywide network of hospitals and clinics; there were no private psychiatric practices. ${ }^{5}$ Large government psychiatric hospitals made up the backbone of the system - in 1954, the USSR

\footnotetext{
${ }^{1}$ A.V. Snezhnevskii, 'Psikhofarmakologicheskie sredstva', in Klinicheskaia psikhiatriia (Izbrannye trudy) (Moscow: Meditsina, 2004), 93. [Original publication: Klinicheskaia meditsina, 10 (1961), 126-34].

2 Edward Shorter, A History of Psychiatry: From the Era of the Asylum to the Age of Prozac (New York: John Wiley, 1997), 279-81; Andrew Scull, Madness: A Very Short Introduction (Oxford: Oxford University Press, 2011), 102-21.

${ }^{3}$ Anne E. Caldwell, Origins of Psychopharmacology from CPZ to LSD (Springfield, IL: Thomas, 1970); Judith Swazey, Chlorpromazine in Psychiatry: A Study of Therapeutic Innovation (Cambridge, MA: Harvard University Press, 1974); David Healy, The Creation of Psychopharmacology (Cambridge, MA: Harvard University Press, 2002); Joanna Moncrieff, The Bitterest of Pills: The Troubling Story of Antipsychotic Drugs (Houndmills: Palgrave, 2013); Nicolas Henckes, 'Magic bullet in the head? Psychiatric revolutions and their aftermath', in Jeremy A. Greene, Flurin Condrau and Elizabeth Siegel Watkins (eds), Therapeutic Revolutions: Pharmaceuticals and Social Change in the Twentieth Century (Chicago: University of Chicago Press, 2016), 65-96.

${ }^{4}$ Nicolas Henckes, 'Reforming Psychiatric Institutions in the Mid-Twentieth Century: A Framework for Analysis', History of Psychiatry, 22, 2 (2011), 165.

${ }^{5}$ Mark G. Field and Jason Aronson, 'The Institutional Framework of Soviet Psychiatry', Journal of Nervous and Mental Disease, 138, 4 (1964), 305-22.
} 
had 187 psychiatric hospitals, with a total of 84,440 beds. $^{6}$ The pharmaceutical industry too was highly centralised, and it was infamous for its shortfalls and poor quality. Like other industries in the Soviet command economy, the pharmaceutical industry suffered from systematic hoarding, false reporting and waste. There was little incentive to produce new products or maintain high quality. ${ }^{7}$ The 'psychopharmacological revolution' in a command economy like the USSR's was thus shaped by a system where decisions were made by a relatively small group of medical officials and where the implementation of those decisions was hampered by the failings of central planning. The result, as historian Volker Hess found in the case of East Germany, was that psychiatrists' plans for the new drugs were frequently undermined by the realities of economic life. ${ }^{8}$

Chlorpromazine, however, arrived in the USSR during the Thaw, a unique period in Soviet history lasting roughly from 1954 to 1957, when 'reform' suddenly seemed possible and when 'de-Stalinisation' was officially endorsed and modelled by Communist leader Nikita Khrushchev. ${ }^{9}$ As Mark B. Adams has argued, for Soviet science, 'things were set into motion [during the Thaw] that would effect the key transition from what we know as "Stalinism" into what became "Brezhnevism". ${ }^{10}$ This is precisely what we find in the case of Soviet psychiatry. During the years of the Thaw, psychiatrists used Aminazine to criticise Stalin-era policies and to advocate for modernisation and more opening to the West. The psychiatrists most associated with Stalin-era policies were put on the defensive. To maintain their positions, they sought to take the lead in researching and popularising the new drugs, using the discourse of modernisation and reform to re-legitimise their authority. At the same time, planning authorities at the USSR Ministry of Health saw Aminazine as a tool that could be used to reform the USSR's system of crumbling, overcrowded psychiatric hospitals by reviving a pre-Stalin-era vision of an ideal socialist psychiatry. The goal of this modernisation plan was not to 'deinstitutionalise' Soviet psychiatry, but rather to build a functioning network of treatment facilities and outpatient 'psychoneurological dispensaries' - a plan that called for building more psychiatric hospitals, not closing old ones. The 'psychopharmacological revolution' thus played a crucial role in how Soviet psychiatrists navigated the Thaw and established a scientific and institutional framework that lasted through the Brezhnev years.

Scholars of the history of Russian and Soviet psychiatry have written very little about this period. Most have focused primarily on the late nineteenth and early twentieth centuries, leaving the history of Soviet psychiatry in the 1950s and 1960s virtually

6 'Godovoi otchet MZ o seti, deiatel'nosti i kadrakh meditsinskikh uchrezhdenii SSSR' [1954], Rossiiskii gosudarstvennyi arkhiv ekonomiki [hereafter RGAE], f. 1562, op. 27, d. 48.

${ }^{7}$ Philip Hanson, The Rise and Fall of the Soviet Economy: An Economic History of the USSR, 1945-91 (London and New York: Routledge, 2014); Donald Filtzer, The Hazards of Urban Life in Late Stalinist Russia: Health, Hygiene, and Living Standards, 1943-53 (Cambridge: Cambridge University Press, 2010), 346-52; Mary Schaeffer Conroy, 'The Soviet Pharmaceutical Industry and Dispensing, 1945-1953', Europe-Asia Studies, 56, 7 (November 2004), 964-67.

${ }^{8}$ Volker Hess, 'Beyond the therapeutic revolution: psychopharmaceuticals crossing the Berlin Wall', in Mat Savelli and Sarah Marks (eds), Psychiatry in Communist Europe (Palgrave, 2015), 153-79.

9 The term 'the Thaw' came from the title of a 1954 novel by Ilya Eherenburg. See Denis Kozlov and Eleonory Gilburd (eds), The Thaw: Soviet Society and Culture during the 1950s and 1960s (Toronto: University of Toronto Press, 2013).

${ }^{10}$ Mark B. Adams, 'Networks in action: the Khrushchev era, the Cold War, and the transformation of Soviet science', in Garland Allen and Roy MacLeod (eds), Science, History and Social Activism, Boston Studies in the Philosophy of Science (Springer Netherlands, 2001), 257. On de-Stalinisation, see Polly Jones, 'Introduction: the dilemmas of de-Stalinization', in Polly Jones (ed.), The Dilemmas of De-Stalinization: Negotiating Cultural and Social Change in the Khrushchev Era (London: Routledge, 2006), 1-18. 
unexplored. ${ }^{11}$ When the psychopharmaceutical revolution has been written about, it has been primarily in relation to the political abuse of psychiatry in the 1960s and 1970s. ${ }^{12}$ This paper focuses instead on how psychiatrists and public health officials responded to the psychopharmaceutical revolution, with particular emphasis on elite psychiatrists and public health officials based in Moscow. Research for this article was conducted in the archives of the USSR and RSFSR Ministries of Health, the Public Health Department of the City of Moscow and the archives of Moscow city psychiatric hospitals. These records of official discussions, inspections and correspondence are analysed together with the published scientific literature of the time. The result is very much a view 'from above'. This paper does not examine how Aminazine affected the experience of being a psychiatric patient in the Soviet Union, a topic which warrants serious research in its own right, ${ }^{13}$ nor does it examine the way in which Aminazine became infamous due to its association with psychiatric abuse. Instead its goal is to provide a foundation for a more historically contextualised view of how the psychopharmacological revolution affected psychiatry in the post-Stalin era.

\section{Chlorpromazine Comes to the USSR}

Chlorpromazine was first synthesised by chemists at the Rhone-Poulenc company in France in December 1950. The scientists who created this drug had been experimenting with compounds derived from phenothiazine, a chemical that had been found to have promising antihistamine characteristics. In a search for more effective antihistamines, they had systematically created different variations of promising molecules and tested them on animals to see if they had significant physiological effects. This research produced a compound dubbed RP 4560, which showed promising signs of acting on the central nervous system. The drug was initially proposed as an anaesthetic. French psychiatrists Pierre Deniker and Jean Delay began to experiment with RP 4560 in late 1951 and early 1952, and it was they who produced the first published report about its potential uses in psychiatry. ${ }^{14}$ By 1953, psychiatrists outside France had begun to test the chemical, now referred to as Chlorpromazine. The first major conference about Chlorpromazine in psychiatry was held in Switzerland in November 1953. Chlorpromazine entered general use in America and Europe in 1954 and became known by its commercial brand names: Largactil in France, Megafen in Germany and Thorazine in the United States. ${ }^{15}$ In 1954 ,

\footnotetext{
11 Julie Vail Brown, 'Heroes and non-heroes: recurring themes in the historiography of Russian-Soviet psychiatry', in Mark S. Micale and Roy Porter (eds), Discovering the History of Psychiatry (New York: Oxford University Press, 1994), 297-307; David Joravsky, Russian Psychology: A Critical History (Oxford: Basil Blackwell, 1989); Martin A. Miller, Freud and the Bolsheviks: Psychoanalysis in Imperial Russia and the Soviet Union (New Haven, CT: Yale University Press, 1998); Irina Sirotkina, Diagnosing Literary Genius: A Cultural History of Psychiatry in Russia, 1880-1930 (Baltimore, MD and London: Johns Hopkins University Press, 2002).

12 Aleksandr Podrabinek, Karatel'naia meditsina (New York: Izd. 'Khronika', 1979), 83-94; Vladimir Bukovskii, 'Psikhiatricheskii GULAG', in Moskovskii protsess (Paris and Moscow: Russkaia mysl', 1996), 14461; Dan Healey, 'Russian and Soviet Forensic Psychiatry: Troubled and Troubling', International Journal of Law and Psychiatry, 37 (2014), 71-81.

13 On the view 'from below', see Benoit Majerus, 'Making Sense of the "Chemical Revolution": Patients' Voices on the Introduction of Neuroleptics in the 1950s', Medical History, 60, 1 (2015), 54-66 and Viola Balz, 'Terra Incognita: An Historiographic Approach to the First Chlorpromazine Trials Using Patients Records of the Psychiatric University Clinic in Heidelberg', History of Psychiatry, 22, 2 (2011), 182-200.

${ }^{14}$ Healy, op. cit. (note 3), 85.

${ }^{15}$ Edward Shorter, A Historical Dictionary of Psychiatry (Oxford: Oxford University Press, 2005), 53-6.
} 
small quantities of Chlorpromazine began to be produced in the USSR under the name Aminazine. ${ }^{16}$

Clinical testing of Aminazine began at the Gannushkin Psychoneurological Hospital in Moscow in October 1954. The patients selected for the study were predominantly women (64 out of 80), most of them suffering from schizophrenia (71\%), though several suffered from 'circular psychosis' and 'presenile psychosis', and two were suffering from 'alcohol psychosis'. ${ }^{17}$ Testing expanded to the RSFSR Institute of Psychiatry in March $1955 .{ }^{18}$ In May, an early progress report on this research was presented to the USSR Ministry of Health by Dr Oleg Kerbikov, a prominent professor of psychiatry who also served as deputy chairman of the USSR Ministry of Health's Council for the Coordination of Scientific Research. ${ }^{19}$ His news was cautious and only mildly optimistic: Aminazine had been found to 'produce a good symptomatic effect' on patients with schizophrenia, but the results 'did not suggest that Aminazine has a direct therapeutic action in schizophrenia'. Since psychiatrists already had other symptomatic treatments, Kerbikov treated Aminazine as more of the same: 'There are no great breakthroughs in this area [the treatment of schizophrenia],' he said. 'One could say that we are occupied with the "politics of small things". ${ }^{20}$ The drug, in other words, did not appear to combat the underlying causes of schizophrenia. It ameliorated the symptoms of the disease, but it was not a cure.

The clinical studies of Aminazine finally concluded in the autumn, and in October 1955 the researchers presented their results at a series of conferences. Published papers appeared in the spring of $1956 . .^{21}$ In one set of patients, 40 out of 63 had seen significant results; in another, the good to excellent results were seen in 16 patients out of $30 .{ }^{22}$ Aminazine's therapeutic effect, one of the lead researchers wrote, "was not lower than insulin coma therapy, and in a number of patients who had been unsuccessfully treated with insulin, Aminazine therapy gave positive results. Aminazine was effective too in individual cases of patients unsuccessfully treated with electroshock therapy. ${ }^{23}$ Although Aminazine did not appear to be a 'magic bullet', then, it did seem to work in some cases, and Soviet psychiatrists were optimistic that it would complement existing methods of treatment. 'The opinion that new methods of treatment [ought to] replace any older methods is incorrect', one participant said. 'The value of Aminazine. . . is in the fact that it is a nonshock therapeutic agent.' 24

Not all were convinced. At the same October 1955 conference, several psychiatrists noted the small sample size and ambiguous results. 'For several patients a long course

\footnotetext{
${ }^{16}$ Aminazine was first synthesised in the USSR by researchers M.N. Shchukina and N.V. Savitskaia at the All-Union Chemical-Pharmacological Scientific Research Institute. M.D. Mashkovskii, S.S. Liberman and A.I. Polezhaeva, 'K farmakologii aminazina', Farmakologiia i toksikologiia, 18, 1 (1955), 14-22; T. A. Nevzorova, Aminazin v klinicheskoi i ambulatornoi praktike (Moscow: Medgiz, 1961), 6.

${ }^{17}$ G.K. Tarasov, 'Rezul'taty klinicheskogo issledovaniia deistviia aminazina pri lechenii psikhicheski bol'nykh', Zhurnal nevropatologii i psikhatrii im. S.S. Korsakova, 56, 2 (1956), 146-54.

18 M.Ia. Sereiskii et al., 'Lechenie bol'nykh shizofreniei aminazinom', Zhurnal nevropatologii i psikhatrii im. S.S. Korsakova, 56, 2 (1956), 155.

${ }^{19}$ O.V. Kerbikov', Zhurnal nevropatologii i psikhatrii im. S.S. Korsakova, 65, 6 (1965), 955-6.

20 'Zasedania Prezidiuma US MZ SSSR', 3 May 1955, Gosudarstvennyi arkhiv Rossiiskoi Federatsii [hereafter GARF], f. r-8009, op. 2, d. 2154, 11. 17-18.

21 'Klinicheskaia konferentsiia sotrudnikov bolnitsyim im. Gannushkina, kafedra psikhiatrii TsIU, Gos. Institute psikhiatrii, i sotrudnikov 3 p-nev dispansarov', 27 October 1955, Tsentral'nyi arkhiv goroda Moskvy [hereafter TsAGM], f. 533, op. 1, d. 27, 11. 49ob-52ob.

22 Tarasov, op. cit. (note 17), 152.

23 Ibid., 154.

24 'Klinicheskaia konferentsiia.. .', op. cit. (note 21), 1. 52.
} 
of treatment was required,' one doctor reported, 'in particular in patients with circular psychosis in manic states. During the process of treatment varying conditions were noted, sometimes improvement, sometimes getting worse. ${ }^{25}$ Other researchers questioned the statistical significance of the results and the methodology involved. One claimed that the rate of recovery was not so different from what she would expect to see spontaneously, without any treatment. ${ }^{26}$ Another participant, a Dr Malakhal'tsev, suggested that researchers had mistakenly assumed that eliminating symptoms (like hallucinations, delusions or depression) was tantamount to curing the disease. The researchers, he said, "took schizophrenia "out of time and space", and in evaluating the action of Aminazine started from the characteristics of the syndrome and not the disease.... From this the use of Aminazine should be seen now as useful only as a symptomatic measure'. ${ }^{27}$

All the teams that studied Aminazine were struck by the way it calmed the body and reduced the symptoms of psychosis. The group at the USSR Institute of Psychiatry reported that, 'Psychomotor agitation, observed in the majority of these patients, quickly vanished under the influence of Aminazine - this was the most clearly pronounced action of the drug.... not only did it eliminate motor and speech agitation, but in a number of cases it caused significant reduction of the strain of delusions and diminished the experience of hallucinations. ${ }^{28}$ The group at the Institute of Advanced Medical Training reported similarly that speech "ceased to be disconnected and toward the end of the course of treatment became normal' ${ }^{29}$ A more extended description was provided by psychiatrists from Kuibyshev University:

At first tension began to diminish and psychomotor agitation was eliminated. Patients became calmer, remained within the confines of their beds, stopped fighting the medical procedures and treatments that were given to them. Motor agitation... disappeared especially fast. The patients' behaviour became more adequate, more orderly. ... [Hallucinations] attracted the patients' attention less and less. Sometimes the character of hallucinations and delusions lingered for a relatively long time, but under the influence of Aminazine treatment they lost their actuality for the patients, they were reflected less in their behaviour. ${ }^{30}$

Psychiatrists immediately recognised that these effects were beneficial not only to patients themselves but also to the psychiatric hospital staff who were interested in establishing calm, well-ordered wards. This was no small matter. As Soviet public health officials privately acknowledged, conditions in psychiatric hospitals were abysmal. The buildings were run-down and poorly funded, the food was inadequate and the wards were desperately overcrowded. Spending on public health had languished in the postSecond World War period, as the State Planning Agency (Gosplan) directed resources to rebuilding industry. ${ }^{31}$ The USSR Ministry of Public Health and subsidiary republic-level and region-level health agencies managed a vast network of struggling hospitals, clinics and epidemiological stations, all of which required funding. Among these, the network of psychoneurological hospitals had low priority. In 1949, the USSR Minister of Public Health had found that, out of the entire Soviet medical system, psychiatry was in the

\footnotetext{
25 Ibid., 11. 48ob.

${ }^{26}$ Ibid., 1. 51ob.

27 Ibid., 1. 52.

28 V.E. Galenko, I. Iu. Osberg and V.D. Azbukina, 'Aminazin v psikhiatricheskoi klinike', Zhurnal nevropatologii i psikhatrii im. S.S. Korsakova, 56, 2 (1956), 162.

29 Tarasov, op. cit. (note 17), 146.

${ }^{30}$ L.L. Rokhlin, M.V. Peskova, and Z.P. Bakhar, 'Opyt lecheniia aminazinom bol'nykh shizofreniei', in L.L. Rokhlin, et al. (eds), Aktual'nye problemy nevropatologii i psikhiatrii (Kuibyshev: MZ RSFSR, 1957), 363.

${ }^{31}$ Filtzer, op. cit. (note 7), 342-53.
} 
worst condition', 32 and matters did not improve in the 1950s. Inspections regularly turned up serious overcrowding, and complaints from relatives of patients revealed systematic and dire neglect. In a 1954 letter denouncing conditions in the hospital where his brother was held, a Communist Party member described 63 patients living in a room intended for 27. Floors were filthy, blankets and pillows were scarcely to be found, underclothes were unwashed, bedbugs were rampant. 'Not by chance,' he wrote, 'did the patient (my brother, 17-year-old V.) fall to his knees in my presence and beg me to take him away from this hell, otherwise they would not let him out alive. ${ }^{33}$

Aminazine was seized upon as a solution that would enable patients to be checked out of these overcrowded wards. Unlike insulin therapy, Aminazine was relatively easy to administer and did not require a special medical ward or day-long supervision by nursing staff. While insulin therapy placed the patient in an insulin coma, Aminazine's risks were more modest. Blood pressure was a concern: patients were to be given thorough medical examinations before being put on a course of Aminazine treatment, and they were told to rest in bed for an hour or two after taking the medicine. ${ }^{34}$ Some patients refused to swallow the medicine because of its 'bitter and unpleasant taste', and so nursing staff ended up adopting a method of injecting the medicine deep into the muscle of the buttocks. ${ }^{35}$ Medical personnel also had to be careful, as many developed rashes in response to the medicine. ${ }^{36}$ In the long term, patients taking Aminazine often developed Parkinsonism. ${ }^{37}$ In the short term, however, Aminazine enabled staff to engage in medical treatment on a much larger scale than before without worrying about causing accidental deaths. The group of psychiatrists working out of Kuibyshev reported that Aminazine had 'noticeably changed the face of the wards. In places where there had been disorderly noise due to the jabbering, agitated, overly active patients, who always fought against everything, it has now become quieter, calmer. ${ }^{38}$

Aminazine's most significant drawback was that its results were not long-lasting. A study published by Moscow clinicians in 1959 compared 84 patients with schizophrenia who had been given insulin shock therapy with 89 patients who had been given Aminazine. They found that most of the Aminazine patients (66 out 84 ) had enjoyed some type of recovery, but that for $63 \%$ of them (40 out the 63 ) the result had lasted less than six months, and that only 10 had enjoyed recoveries lasting two years or more. In contrast, a majority of insulin-therapy patients had enjoyed recoveries lasting longer than six months, and in 29 out of 61 cases the result had lasted two years or more. ${ }^{39}$ Aminazine therapy might be convenient, the RSFSR Ministry of Health reported in 1960, but 'the therapeutic effectiveness of Aminazine in schizophrenia... is not lasting'. 'Recidivism often follows,'

\footnotetext{
32 'Stenogramma zasedanii Kollegii MZ SSSR', 11 February 1949, GARF, f. r-8009, op. 1, d. 757, 1. 119.

33 Letter to the editor of Pravda, 26 October 1954, GARF, f. r-8009, op. 33, d. 648-ts, 11. 93-5, 100-2.

34 Nevzorova, op. cit. (note 16), 113.

35 T.L. Taranenko, 'Vidoizmenenie sposoba vnutrimyshechnogo vvedeniia aminazina i ukhod za bol'nymi vo vremia lecheniia etim preparatom', Meditsinskaia sestra, 6 (1958), 32.

36 'Instruktsiia po lecheniiu aminazinom psikhicheski bol'nykh', 1959, GARF , f. r-8009, op. 1, d. 1371b, 11. 26-7, 55-7; Nevzorova, op. cit. (note 16), 25.

${ }^{37}$ Galenko et al., op. cit. (note 28), 156. Soviet psychiatrists summarised and publicised international findings about the side effects and complications of Chlorpromazine treatment in 1958. G.K. Tarasov, 'O neirolepticheskom sindrome', Zhurnal nevropatologii i psikhatrii im. S.S. Korsakova, 58, 2 (1958), 234-7.

${ }^{38}$ Rokhlin, Peskova and Bakhar, op. cit. (note 30), 363.

39 T. A. Nevzorova, 'Sravnitel'naia terapevticheskaia effektivnost' insulina i aminazina pri lechenii bol'nykh shizofreniei', Zhurnal nevropatologii i psikhatrii im. S.S. Korsakova, 59, 2 (1959), 161.
} 
the report concluded, 'which increases the number of repeat hospitalisations.' 40 The solution was to administer 'supporting' doses of Aminazine as needed over the course of the patient's life. Major mental illness was on its way to being conceptualised as a chronic condition that one could manage with pharmaceuticals.

Late in 1955, Aminazine was officially approved for production. ${ }^{41}$ It was still just one of several major methods of 'active treatment'. Insulin therapy was considered just as effective, and other forms of shock therapy and sleep therapy were also in widespread use, as were 'symptomatic' treatments such as sedatives. ${ }^{42}$ As the use of Aminazine increased over the years 1956-60, however, Soviet psychiatric hospitals reported using fewer of these other 'active methods'. In 1960, Aminazine was given to patients four times as often as insulin therapy. ${ }^{43}$ 'Symptomatic' treatments declined too, including such drugs as barbiturates and long-used methods like warm baths. ${ }^{44}$ Insulin therapy was still used, but it was increasingly a treatment reserved for 'patients with very longstanding illness', a last resort when Aminazine failed. ${ }^{45}$ These patients often failed to respond to insulin therapy too and, as a result, insulin therapy was reported to be less effective than it had been in earlier years. A study of five major psychiatric hospitals in the RSFSR found in 1955 that insulin shock therapy produced a full recovery in $12 \%$ of patients; by 1960 , however, that rate had fallen to $6.3 \%$. Insulin shock therapy had begun its long slide into disuse, while Aminazine and the quickly burgeoning cornucopia of similar drugs emerged as the gold standard of treatment for mental illness.

Increasing reliance on psychopharmaceuticals, however, meant that Soviet psychiatry suffered proportionately from the Soviet planned economy's infamous shortfalls and poor quality. ${ }^{46}$ In the 1940 s and 1950 s, the USSR Ministry of Health repeatedly issued decrees insisting that the Soviet pharmaceutical industry supply medications without interruption. ${ }^{47}$ The need to reissue such decrees suggests that their efforts were unsuccessful. This is supported by government archives, which are filled with complaints about lack of medicine and pleas for more. In 1957, one of the first years Aminazine was available, the psychiatry office at the RSFSR Ministry of Health reported that staff spent two thirds of their time working on letters of complaint, and that letters asking for Aminazine made up a 'large portion' of those letters. ${ }^{48}$ Increased production did not solve the problem; yet another major shortfall in Aminazine supply was reported in $1960 .^{49}$ In 1966, the USSR Ministry of Health issued (yet another) decree mandating that high-priority psychiatric drugs be available without fail. ${ }^{50}$ Despite these orders the

40 ‘Obzor deiatel'nosti psikhonevrologichesikh bol'nits RSFSR za 1960 god', GARF, f. a-482, op. 50, d. 5188, 1. 55.

41 'Otchet o rabote komitetov i komissii pri UMS MZ SSSR', 10 February 1956, GARF, f. r-8009, op. 2, d. 2479, 1. 14.

42 'Godovoi meditsinskii otchet bol'nitsy [Kashchenko] za 1956 god', TsAGM, f. 4-389, op. 1, d. 94, 11. 11-12.

43 Nevzorova, op. cit. (note 39), 161, 165.

44 'Obzor deiatel'nosti', op. cit. (note 40), 1. 59.

45 Ibid., 1. 51.

${ }^{46}$ Hanson, op. cit. (note 7); Filtzer, op. cit. (note 7), 346-52; Conroy, op. cit. (note 7), 964-7.

47 'Reshenie kollegii MZ SSSR', 11 February 1949, GARF, f. r-8009, op. 1, d. 757, 1. 25.

48 'Otchet o rabote otdela po razdachu psikhonevrologicheskoi pomoshchi za 1957 god', GARF, f. a-482, op. 50, d. $3570,11.46-7$.

49 'Spisok medikamentov, vydelennykh na 1960 god v nedostatochnykh kolichestvakh', GARF, f. a-482, op. 50, d. $4984,1.75$.

50 'Prilozhenie no. 1 k prikazu MZ SSSR 170', 12 March 1966, GARF, f. r-8009, op. 1, d. 1511, 1l. 7-9. 
Soviet pharmaceutical industry continued to struggle to consistently deliver the needed medication.

The shortfall of Aminazine created a dilemma for psychiatrists and patients alike. Some psychiatric hospitals seem to have gone around the Ministry of Health and found ways to get the medication directly from the factories that produced it, a practice that further disrupted the organised supply of the drug. ${ }^{51}$ When prescriptions could not be filled at hospital pharmacies, patients went in search of it elsewhere, and not surprisingly a black market in Aminazine seems to have developed, supplied at least in part by psychiatric staff who pilfered drugs from their workplace. ${ }^{52}$ Reports surfaced that psychiatrists were informing people that they would need to get the drug on their own, since the psychiatric hospitals did not have enough. Some families went directly to the pharmaceutical industry to buy the drug, while others appealed to the Ministry of Health. In 1958, the RSFSR Ministry of Health issued an order reminding psychiatrists that 'Aminazine is not freely for sale', and that it could only be purchased if prescribed by a physician. ${ }^{53}$ Dispensaries reported serious problems with the effectiveness of supporting therapy because patients were hoarding their medicine, taking only partial doses and sometimes selling it on the black market. ${ }^{54}$ The pharmaceutical industry, however, continued to struggle to produce enough of the drugs. These supply issues threatened to undermine the functioning of a psychiatric medicine system that was increasingly dependent on psychopharmaceuticals at every level.

\section{Psychopharmacology and Professional Politics during the Thaw}

During the Stalin era, the Soviet psychiatric profession had become highly centralised and increasingly dogmatic. In the 1920s, several psychiatry journals had continued to publish, and Soviet psychiatrists had remained relatively connected to science in the West, but by the end of the 1930s only a single journal remained, The Korsakov Journal of Neuropathology and Psychiatry, and the Communist Party was becoming increasingly intolerant of foreign connections. In 1936, the Communist Party intervened in psychiatry to censure the leading psychiatric research institute for focusing on the social causes of mental illness. New leaders were brought in and the 1920s-era focus on outpatient care was replaced by new attention to treating (and discovering) the physiological causes of mental illness. ${ }^{55}$

In the late 1940s and early 1950s, this approach to mental illness was further constrained when the Communist Party began to require Soviet medical personnel to base their work

${ }^{51}$ E.P. Egorovskaia (Zam. nachal'nika otdela spets. pomoshchi MZ RSFSR) to Z.G. Gurevich (Gl. Aptechnoe Upr.), 22 August 1956, GARF, f. a-482, op. 50, d. 1325, 1. 88-90.

52 'Prikaz \#153 po psikhonev. Gorodskoi bol'nitse \#3 im. Giliarovskogo', 11 June 1956, TsAGM, f. 1126, op. 1, d. 95, 1. 21; 'Prikaz 324 po psikhonev. gorodskoi bol'nitse \#4 im. Gannushkina', 18 July 1962, TsAGM, f. 533, op. 1, d. 55, 11. 67-67ob.

${ }^{53}$ Lavrishchev (Zam. nach. Gl. lechebno-prof. upravl. MZ RSFSR) to MZ ASSR, Zaved. obl. krai. Gorzdravotdelami Respub., kraevym, oblastnym, gorodskim psikhiatram, Glavnym vracham psikhonev. bol'nits i dispanserov, 1 May 1958, GARF, f. a-482, op. 50, d. 3568, 1. 101.

54 'Ob'iasnitel'naia zapiska k godovomu stat. otchetu psikho-nev. dispansera Leningradskogo Raiona za 1964 god', undated [1964], TsAGM, f. r-551, op. 1, d. 1547, 11. 38-9.

55 Benjamin Zajicek, 'Soviet Madness: Nervousness, Mild Schizophrenia, and the Professional Jurisdiction of Psychiatry in the USSR, 1918-36', Ab Imperio, 4 (2014), 167-94; Benjamin Zajicek, 'A Soviet system of professions: psychiatry, professional jurisdiction, and the Soviet Academy of Medical Sciences, 1932-51', in Susan Grant (ed.), Russian and Soviet Health Care from an International Perspective: Comparing Professions, Practice and Gender, 1880-60 (Palgrave Macmillan, 2017), 97-117. 
on Ivan Pavlov's 'theory of higher nervous activity'. Pavlov had used his study of dogs and conditional reflexes to create an elaborate theory of brain physiology in which he postulated that at a physiological level all 'higher nervous activity' could be understood as an interaction between two fundamental processes, 'excitation' and 'inhibition'. He used these terms in his own idiosyncratic way. They did not describe the action of neurons or synapses; rather, Pavlov believed he was mapping the regularities of a higher order of whole-brain activity. ${ }^{56}$ In 1950 and 1951, every Soviet medical discipline was ordered to hold 'scientific discussions' about Pavlov's theory and to denounce colleagues who were relying on Western, non-Pavlovian ideas. ${ }^{57}$ Psychiatrists held their meeting in October 1951, and many of the most prominent Soviet psychiatric researchers and professors were removed from their posts. Going forward, psychiatrists were to use Pavlov's conditional reflex methods to research and treat mental illness. ${ }^{58}$

The psychiatrist most closely associated with these late-Stalin-era policies in psychiatry was Andrei Snezhnevskii. Before 1950 he had been a little know researcher and administrator, but in 1950 he was plucked from obscurity and put in charge of purging leading psychiatric research facilities (including the infamous Serbsky Institute), and he was chosen to deliver the main address at the 1951 Pavlov Session in psychiatry. By 1952, Snezhnevskii had become the dominant figure in Soviet psychiatry, holding key administrative and teaching posts and serving as the editor of The Korsakov Journal. He served as an important gatekeeper and enforcer, controlling research funding and making publication contingent on strict Pavlovism. ${ }^{59}$ The death of Stalin and the advent of the Thaw put Snezhnevskii's position in peril, as other psychiatrists began to criticise Stalinera policies in their field and advocate for reform. In the 1970s, both Aminazine and Snezhnevskii became synonymous with the abuse of psychiatry to suppress dissent. ${ }^{60} \mathrm{In}$ the 1950s and early 1960s, however, Aminazine became a symbol of modernisation and transition away from Stalinism, and Snezhnevskii used it to re-legitimise his claim to professional dominance in the post-Stalin era.

The first tentative steps toward criticism of Snezhnevskii and Stalin-era dogma came in December 1953, when Snezhnevskii's stewardship of The Korsakov Journal was criticised. Under Snezhnevskii, The Korsakov Journal had filled its pages with studies that used Pavlov's 'objective pathophysiological methods'. ${ }^{61}$ In practice this meant research studies that attempted to find patterns in the conditional reflexes of patients suffering from various psychoses, and in studies of sleep therapy. Sleep therapy was the Pavlovian treatment par excellence. In the 1920s, Pavlov had hypothesised that sleep induced a state of 'protective inhibition' in which the brain protected and repaired the cells in the cerebral

\footnotetext{
56 Daniel P. Todes, Ivan Pavlov: A Russian Life in Science (Oxford: Oxford University Press, 2014), 287-302; Roger Smith, Inhibition: History and Meaning in the Sciences of Mind and Brain (Berkeley, CA: University of California Press, 1992), 200-5; Joravsky, op. cit. (note 11), 295.

${ }^{57}$ Ethan M. Pollock, Stalin and the Soviet Science Wars (Princeton, NJ: Princeton University Press, 2006), chapter 6 passim; Nikolai Krementsov, Stalinist Science (Princeton, NJ: Princeton University Press, 1997), 2725; Joravsky, op. cit. (note 11), chapter 14 passim.

58 George Windholz, 'Soviet Psychiatrists under Stalinist Duress: The Design for a "New Soviet Psychiatry" and Its Demise', History of Psychiatry, 10, 3 (1999), 329-47; Benjamin Zajicek, 'Banning the Soviet Lobotomy: Psychiatry, Ethics, and Professional Politics during Late Stalinism', Bulletin of the History of Medicine, 91, 1 (2017), 33-61.

59 Joravsky, op. cit. (note 11), 425-226.

${ }^{60}$ Robert van Voren, Cold War in Psychiatry: Human Factors, Secret Actors (Amsterdam and New York: Rodopi, 2010).

61 'Stenogramma zasedaniia Prezidiuma US MZ SSSR', 18 December 1953, GARF,f. r-8009, op. 2, d. 1925, 11. $22-7$.
} 
cortex. He speculated that prolonged sleep therapy enabled protective inhibition to cure serious mental illness like schizophrenia, which he believed was caused by a "chronic hypnotic state that resulted when a cortex weakened either by heredity or experience was subjected to an "overwhelming excitation". ${ }^{62}$. After the 'Pavlov Session' in psychiatry, sleep therapy began to dominate the pages of The Korsakov Journal. Eighteen papers on sleep therapy were published in 1953 alone, four times as many as had been published in the previous three years. ${ }^{63}$ The USSR's most prominent Pavlovian psychiatrist went so far as to suggest that sleep therapy ought to be used not only for neuroses and mental illnesses but for any somatic illness which could be 'connected with the overstraining of the nervous system' ${ }^{64}$ The USSR Ministry of Health began to avoid using the term 'psychiatry' altogether, referring to it instead as 'clinical pathophysiology of higher nervous activity'. ${ }^{65}$

After Stalin's death, in March 1953, the USSR Ministry of Public Health appointed a commission to examine the editorial policies at the journal, and their report was discussed by the Scientific Medical Council of the USSR Ministry of Public Health in December 1953. Many of the elite psychiatric research directors and professors of the USSR were present, as were members of the commission itself. The authors of the report criticised the editors of the journal for failing to publish reviews of new psychiatric publications from outside the USSR, and for the lack of clinical research papers. By publishing only Pavlovian laboratory research, they claimed, Snezhnevskii had allowed The Korsakov Journal to 'lose its character as a clinical journal'. ${ }^{66}$ The editors were accused of rejecting good research papers simply because they did not reflect the editors' personal views, and of publishing only work that had been written by members of the editorial board or researchers who worked under them. ${ }^{67}$ They were guilty, the report concluded, of 'suppressing broad democracy' within Soviet psychiatry. ${ }^{68}$

Snezhnevskii himself was invited to speak on his own behalf, and he defended his stewardship of the journal. He attacked the quality of the inspection, challenging his critics to provide examples of alleged 'vulgarisation of Pavlov's ideas' and defending the clinical focus of the journal. He admitted that the journal could improve its coverage of research being done outside Moscow but maintained that the quality of research articles submitted from the provinces was generally lower than that done in central institutes. He was willing to concede that the journal needed more coverage of psychiatry being done abroad. ${ }^{69}$ Other members of the editorial board supported him; they too called for the journal to continue its Pavlovian course, to do a better job of publicising the work of psychiatrists in the Soviet sphere of Eastern Europe and to increase its coverage (and 'criticism') of Western research. $^{70}$

62 Todes, op. cit. (note 56), 632, 647-8.

63 'Sistematicheskii ukazatel', Zhurnal nevropatologii i psikhatrii im. S.S. Korsakova, 53, 12 (1953), 965.

${ }^{64}$ E. Sh. Airapet'liats et al. (eds), Nauchnaia sessiia posviashchennaia problemam fiziologicheskogo ucheniia akademika I.P. Pavlova, 28 iiunia - 4 iiulia 1950 g.: Stenograficheskii otchet (Moscow: Izd. Akademii Nauk SSSR, 1950), 59.

65 'Stenogramma. . ', op. cit. (note 61), 1. 33.

66 'Otchet Komissii po oblsedovaniiu zhurnala “Nevropatologii i psikhiatrii im. Korsakova”', 15 December 1953, GARF, f. r-8009, op. 2, d. 1925, 11. 43-6.

${ }^{67}$ N. Chetverikov, 'Nekotorye zamechaniia o rabote Zhurnala nev. i psikh im. Korsakova', 12 December 1953, $G A R F$, f. r-8009, op. 2, d. 1925, 1. 56.

68 'Stenogramma. . ', op. cit. (note 61), 11. 24-5.

${ }^{69}$ Ibid., 11. 26-8.

${ }^{70}$ Ibid., 11. 29-34. 
In 1954 and 1955, therefore, The Korsakov Journal continued to publish research that used Pavlovian conditional reflex methods and Pavlovian 'neurodynamic concepts'.71 At the same time, for the first time since the mid-1940s, the journal began to publish abstracts and reviews of foreign research, including a review article published in 1955 that summarised the early Chlorpromazine research conducted in France, Germany, Britain and the United States. ${ }^{72}$ The review, written by a psychiatrist working in Snezhnevskii's institute in Moscow, attributed the effects of the drug to Pavlov's 'protective inhibition' and called on Soviet researchers to 'study the mechanism of action instigated by phenothiazine in the experiment and clinic on the basis of the theory and methods of Pavlovian physiology' ${ }^{73}$

Psychiatrists outside Snezhnevskii's laboratory used early Aminazine research to challenge the orthodox Pavlovian view that the conditional reflex method was the only way to scientifically study the laws of 'higher nervous activity'. In 1954, a few Soviet psychiatrists began to research the relationship between brain chemistry and mental illness. Several speakers at an important 1954 conference sketched research agendas that could be described as seeking to understand the biochemical mechanisms of mental illness. ${ }^{74}$ The implication was that there might be physiological mechanisms that were more fundamental to brain function than Pavlov's 'excitation' and 'inhibition'. The discipline of psychiatry, therefore, was not simply an applied branch of neurophysiology. By 1955 and 1956, researchers were openly claiming that Aminazine should be thought of as a tool for applying the scientific method to the study of the physiology of the brain and its relationship to thought. One author, Nikolai Timofeev, claimed that dogmatic Pavlovians had actually harmed Pavlov's own legacy by preventing research on psychopharmacology, something that 'could not help but cause sorrow'. 'Within our specialty,' Timofeev wrote, 'the desire of I.P. Pavlov to expand pharmacology in the direction of therapy as experimental science remained unrealised. ${ }^{75}$ It was now psychoactive drugs, not conditional reflexes, which were being touted as the key to creating a rational scientific foundation for modern psychiatry.

By the end of 1955, Snezhnevskii's journal had all but ceased to publish Pavlovian conditional-reflex research and was devoting more and more of its pages to Aminazine research. The journal's work was subject to a discussion at a plenum of the All-Union Society of Neuropathologists and Psychiatrists in February 1956, and Snezhnevskii used the opportunity to emphasise Aminazine research as the cutting edge of contemporary psychiatry. He pointed out that the journal was no longer publishing 'purely declarative'

\footnotetext{
${ }^{71}$ Iu. E. Segal', 'K neirodinamike sosudistykh refleksov pri galliutsinnatorno-paranoidnoi forme shizofrenii. Soobshchenie I', Zhurnal nevropatologii i psikhatrii im. S.S. Korsakova, 53, 3 (1953), 182-90; D.A. Kaufman, 'K voprosu o patofiziologii shizofrenicheskogo defekta', Zhurnal nevropatologii i psikhatrii im. S.S. Korsakova, 53, 4 (1953), 259-66.

72 G.K. Tarasov, 'Aminazin (Obzor literatury po primeneniiu v psikhiatrii odnogo iz proizvodnykh fenotiazina)", Zhurnal nevropatologii i psikhatrii im. S.S. Korsakova, 55, 4 (1955), 296-310.

73 Ibid., 308.

${ }^{74}$ E. Ia. Skuin', 'K voprosu o prirode biokhimicheskikh sdvigov pri terapii shizofrenii', in V.M. Banshchikov et al. (eds), Trudy Vsesoiuznoi nauchno-prakticheskoi konferentsii posviashchennoi 100-letiiu so dnia rozhdeniia S.S. Korsakova i aktual'nym voprosam psikhiatrii (Moscow: Medgiz, 1955), 356-8.

${ }^{75}$ N.N. Timofeev, 'O psikhofarmakologii i ee otnoshenii k drugim metodam terapii psikhozov', Zhurnal nevropatologii i psikhatrii im. S.S. Korsakova, 58, 2 (1958), 129-37: 129.
} 
articles or articles that were guilty of 'speculative physiology'. ${ }^{76}$ By focusing on new methods of study and treatment, he concluded, 'the journal has drawn significantly closer to practice, to the bedside of the patient'. ${ }^{77}$ The journal had gone so far as to lobby the USSR's pharmacology research institute to speed up industrial production of Aminazine, and had planned a special enlarged issue of the journal that would focus exclusively on Aminazine. ${ }^{78}$ Aminazine research - much of it conducted in Snezhnevskii's own department at the Institute for Advanced Medical Study - was now the symbol of advanced psychiatric science, and by throwing his support fully behind it Snezhnevskii was able to fashion himself as a reformer and de-Staliniser, a practical administrator seeking to rectify mistakes of the past.

By 1956, Soviet psychopharmacology research was flourishing with the encouragement and sponsorship of Snezhnevskii and the Moscow psychiatric establishment. Sleep therapy vanished from the pages of The Korsakov Journal, supplanted by studies of Aminazine. Among the first issues examined was the question of how Aminazine worked. Did it act directly on the physiological causes of mental illness, or did it somehow influence the body in general, affecting the disease process only indirectly? Soviet researchers found Aminazine at higher concentrations in the cerebral cortex than in other parts of the central nervous system and correlated Aminazine with reversible changes in the cells of the cerebral cortex itself. They suggested that these results could be interpreted to mean that Aminazine acted directly on the underlying physiological causes of the illness, and that mental illness itself was caused by changes in brain chemistry. ${ }^{79} \mathrm{~A}$ series of articles published in 1959 explored the interaction between Aminazine and physical processes such as protein synthesis and the permeability of the blood-brain barrier. ${ }^{80}$ The results were ambiguous, but they reinforced the impression that by studying the physiological effects of Aminazine researchers could get closer to understanding the physiological causes of mental illness. This conclusion was further driven home by reports from the West about the ability to induce symptoms of psychosis using another new drug, LSD, and then to eliminate those symptoms using Chlorpromazine. ${ }^{81}$ Snezhnevskii's journal published a comprehensive review of ten years of European and American research on LSD, concluding that it had 'significant interest and may help in understanding the mechanism of development of psychoses and their cure' ${ }^{82}$ There was a growing sense in the Soviet Union that Aminazine andother new psychoactive drugs were different from

\footnotetext{
76 'Stenogramma zasedaniia Plenuma pravleniia vsesiouznogo obshchestva nevropatologov i psikhiatrov', GARF, f. r-9592, op. 1, d. 39, 1. 3.

77 Ibid., 1. 12.

78 Ibid., 11. 6, 11.

79 B.S. Bamdas et al., 'Materialy k mekhanizmu deistviia aminazina', Zhurnal nevropatologii i psikhatrii im. S.S. Korsakova, 56, 2 (1956), 132-6; K.V. Stroikova, 'O lokalizatsii deistviia aminazina u bol'nykh shizofreniei', Zhurnal nevropatologii i psikhatrii im. S.S. Korsakova, 59, 9 (1959), 402-9.

${ }^{80}$ L. I. Lando, 'Elektroforeticheskoe issledovanie belkovykh fraktsii syvorotki krovi bol'nykh shizofreniei i ikh dinamiki pod vlianiem lecheniia neirolepticheskimi veshchestvami', Zhurnal nevropatologii i psikhatrii im. S.S. Korsakova, 59, 2 (1959), 135-42; N.N. Lapteva, 'K mekhanizmu vliianiia aminazina na belkovyi sostav plazmy krovi', Zhurnal nevropatologii i psikhatrii im. S.S. Korsakova, 59, 2 (1959), 143-50; T.E. Romel', 'Pronitsaemost' gemato-entsefalicheskogo bar'era i ee izmenenie pod vlianiem aminazinoterapii u bol'nykh shizofreniei', Zhurnal nevropatologii i psikhatrii im. S.S. Korsakova, 59, 2 (1959), 151-5.

${ }^{81}$ Healy, op. cit. (note 3), 107.

${ }^{82}$ V.M. Banshchikov and G.V. Stoliarov, 'Eksperimental'nye psikhozy: Dietilamid lizerginovoi kisloty v psikhiatrii (Obzor zarubezhnoi literatury)', Zhurnal nevropatologii i psikhatrii im. S.S. Korsakova, 59, 2 (1959), 222-32.
} 
other methods of treatment because these new drugs enabled psychiatrists to use laboratory methods to understand the physiological mechanisms of mental illness.

By 1960, Aminazine was no longer the only drug being tested in Soviet psychiatry. Reserpine, a drug synthesised from the plant Rauwolfia, was being used in the USSR by 1956, though Soviet industrial production of Reserpine did not begin until late 1957 (much to the frustration of medical officials). ${ }^{83}$ In 1958-60, the Soviet government imported new psychiatric drugs as they were created in the West and tested them in Moscow psychiatric hospitals. ${ }^{84}$ In these clinical trials, groups of 100 patients were given the new drug, with half of them getting it in combination with Aminazine or another drug. The official instructions for conducting such clinical trials called for a control group to be given a placebo, ${ }^{85}$ but archival records do not indicate whether control groups were used. ${ }^{86}$ Snezhnevskii's department at the Institute for Advanced Medical Study continued to oversee these studies. Among them were not only Aminazine-like phenothiazines but also new anti-depressants, including Miltown (Meprotan), the blockbuster 'tranquiliser' then taking America by storm. ${ }^{87}$ By 1966, the Soviet government had created a list of ten psychiatric drugs that were to be given the highest priority by the pharmaceutical industry. ${ }^{88}$

Soviet psychiatrists did not wholly abandon Pavlovian theory during these years: studies were conducted on the effect of Aminazine on conditional reflexes, and Pavlovian concepts continued to inform medical and scientific thinking. The real significance of psychopharmacology, however, lay in the way that Snezhnevskii and researchers associated with him used it to reassert the independence of psychiatry from physiology. Clinical observations of patients, they argued, could produce new scientific knowledge that was impossible to glean from laboratory research. They enlisted Aminazine, and later other psychoactive drugs, to help them document the complex differences between different subtypes of schizophrenia and to describe the typical development

${ }^{83}$ M. Kislov (Nach. Gl. Aptechnogo upr. MZ RSFSR) to Safonov A.G. (Nach. Gl. Lech-prof. Upr. MZ RSFSR), 18 September 1956, GARF, f. a-482, op. 50, d. 1325, 11. 83-5; 'Stenogramma zasedaniia Preiziduma UMS MZ SSSR', 26 February 1957, GARF, f. r-8009, op. 2, d. 2314, 1. 46. David Healy notes that in Western scientific literature reserpine was mentioned much more than Chlorpromazine, and it was crucial for testing theories about serotonin and dopamine. This Western research was reported in the Soviet Union, but Soviet authors themselves published very little reserpine research, perhaps because they had difficulty getting access to it. Healy, op. cit. (note 3), 106; V.M. Morozov, 'Novoe v terapii psikhicheskikh zabolevanii', Zhurnal nevropatologii i psikhatrii im. S.S. Korsakova, 56, 7 (1956), 591-9.

84 Tarasov, 'Rezul'taty klinicheskogo issledovaniia novykh lekarstvennykh sredstv, provedennogo v institute psikhiatrii MZ RSFSR v 1958-60 godakh', in Sovremennye metody lecheniia psikhicheskikh zabolevanii: Metodicheskie materialy v pomoshch' prakticheskomu vrachu, L.L. Rokhlin and G.K. Tarasov (eds) (Moscow: MZ RSFSR, 1961), 5-14.

85 I.G. Ravkin and M.S. Zeleva, Polozhenie o klinicheskoi proverke novykh lekarstvennykh sredstv v usloviiakh psikhonevrologicheskogo statsionara', in L.L. Rokhlin and G.K. Tarasov (eds), Sovremennye metody lecheniia psikhicheskikh zabolevanii: Metodicheskie materialy v pomoshch' prakticheskomu vrachu (Moscow: MZ RSFSR, 1961), 56-8.

${ }^{86}$ A set of clinical trial records can be found in $T s A G M$, f. 533, op. 1, d. 156. See, for instance, 'Rezul'taty klinicheskogo ispytaniia meprotan (andaksin) na baze kafedry psikhiatrii TsIU i klinicheskoi psikhonevrologicheskoi b-tsy \#4 im. Gannushkine', TsAGM, f. 533, op. 1, d. 156, 11. 1-4.

87 Tarasov, op. cit. (note 84), 11-12. On America's 'popular frenzy' for Miltown, see Shorter, op. cit. (note 2), $315-6$.

88 These drugs included Aminazine, Haloperidol, Imizin (Melipramin), Meprotan (Meprobomat), Mazheptil (Thioproperazine), Tisercin (Levomepromazine), Transamin (Tranexamic Acid), Triftazin (Trifluoperazine), Etaperazin (Perphenazine) and Elenium (Librium). B. Petrovskii, 'Perechen' vazhneishikh meditsinskikh preparatov, kotorymi neobkhodoimo obespechit' uchrezdheniia zdravookhraneniia v dostatochnykh kolichestvakh pervoocheredno', 26 January 1966, GARF, f. r-8009, op. 1, d. 1511, 1. 10. 
of one group of symptoms into another. Using this descriptive approach, Snezhnevskii claimed, psychiatrists could 'uncover new laws [zakonomernosti] of development of individual mental illnesses, expressed outside the particularities of their pathogenesis - the qualities of pathological process, developing in the brain'. ${ }^{89}$ Aminazine and other psychopharmaceuticals seemed to affect different subtypes of schizophrenia differently, confirming that the observed symptoms had some basis in different underlying processes in the body. Snezhnevskii described the action of these new drugs as directly targeted at particular diseases:

In depressive-paranoid syndrome, delusions and hallucinations are eliminated by therapy with Aminazine; the condition then takes on a purely depressive character. On the other hand, if Tofranil is used on the same condition, depression vanishes, but delusions and hallucinations remain or even increase. . . These observations indicate the particular targeted-ness of the action of psychotropic substances, opening the possibility of acting on individual parts of the pathogenesis of the pathological process. ${ }^{90}$

The new drugs, in this telling, were like 'lock and key', each fitting the underlying physical causes of a particular illness and revealing the true taxonomy of mental illness.

Snezhnevskii made much of the fact that drug treatments seemed to cause some patients to switch from one symptom-complex to another. He used this insight as the foundation for his increasingly ambitious theories about psychopathology. Most psychiatrists since Kraepelin had attempted to identify distinct disease entities; by definition, one disorder could not turn into another. An older tradition, however, claimed that the boundaries between mental disorders were not nearly so absolute. Snezhnevskii cited examples of psychiatrists going back to nineteenth-century French psychiatrist Valentin Magnan, who had described one syndrome developing into another, such as 'the transition of paranoid syndrome, syndrome of compulsiveness and dysmorphophobia into the syndrome of mental automatism and paraphrenic syndrome; delirium - to amentia, asthenic syndrome to delirium or amentia' and so forth. ${ }^{91}$ Snezhnevskii's essential claim was that syndromes should not be seen as specific to any disease entity, but that the sequence in which they developed from one into another was subject to natural laws and reflected the complex underlying conditions of the brain, conditions that were affected by both individual physiology and particular disease pathology. The new psychopharmacology, Snezhnevskii claimed, had enabled Soviet researchers to make sense of these observations and begin to systematise them..$^{92}$ Clinical psychiatry was now able to assert itself as an independent science that could make original contributions to medical knowledge; it was no longer to be understood simply as 'applied pathophysiology of higher nervous activity'.

\section{Psychoneurological Dispensaries and Outpatient Treatment}

Psychopharmaceuticals arrived in the USSR at a time when the Communist Party was publicly claiming that it would prioritise the basic needs of Soviet citizens, pivoting away from Stalin's narrow focus on heavy industry and giving more attention to the construction of housing, the production of consumer goods and the general improvement of quality of

\footnotetext{
${ }^{89}$ A.V. Snezhnevskii, 'Psikhopatologiia', in Klinicheskaia psikhiatriia (Izbrannye trudy) (Moscow: Meditsina, 2004), 102. [Original publication: Bol'shaia meditsinskaia entsiklopediia, vol. 27, 2nd edn (Moscow: Sovetskaia entsiklopediia, 1962), 372-92.].

90 Ibid., 95.

91 Snezhnevskii, op. cit. (note 1), 96.

92 A.V. Snezhnevskii, 'O nozologicheskoi spetsifichnosti psikhopatologicheskikh sindromov', Zhurnal nevropatologii i psikhatrii im. S.S. Korsakova, 60, 1 (1960), 91-107.
} 
life. Public health officials announced plans to improve hospitals and care, particularly the psychiatric system. In July 1954, the USSR Council of Ministers issued an order instructing the Ministry of Health to increase construction of psychiatric hospitals and neuropsychiatric dispensaries in the 1955-60 period. ${ }^{93}$ The goal of this reform was clearly stated: 'in contrast to past psychiatric hospitals, Soviet psychoneurological hospitals set before themselves the task of the treatment, not confinement, of patients' ${ }^{94}$ In February 1956, the USSR Ministry of Health formally issued a five-year plan to increase the number of Soviet hospitals by $28 \%$, giving priority to psychiatric beds, which were to be increased $49.8 \% .{ }^{95}$ Aminazine had just been approved for industrial production, and public health officials saw it as a technological solution to the problem of overcrowding in the psychiatric system. Not only could patients be checked out more quickly, their treatment could now largely be done 'in the community'. As one Soviet psychiatrist noted at a 1955 clinical conference, 'here it is possible to pose the question of supporting therapy in ambulatory practice'. ${ }^{96}$ Aminazine would allow for more efficient management of hospitals while simultaneously realising one of the ideological goals of early Soviet public health officials: a comprehensive system of community-based psychiatry where psychiatric hospitals played only a supporting role.

Soviet psychiatrists were not alone in seeing the new psychopharmacology as a solution to problems of overcrowded asylums. In the 1940s and 1950s, American psychiatric hospitals were widely criticised for their inhumane conditions. American popular culture depicted psychiatric treatments as punitive, damaging and unscientific, and asylums were 'The Shame of the States', to quote the title of one of the most famous exposés of the time. ${ }^{97}$ The Community Mental Health Act of 1963, signed into law by President Kennedy, was based on the idea that, with the help of Chlorpromazine, patients could live outside psychiatric hospitals and be treated in Community Mental Health Centers. Federal funding to these centres encouraged the massive 'deinstitutionalisation' of the American psychiatric system in the 1960s and 1970s. The number of psychiatric hospital beds in the United States fell from a high of 559000 in 1955 to 338000 in 1970, then continued to decline to 107000 in $1988 . .^{98}$

Soviet psychiatrists hailed the Community Mental Health Centres as a progressive step for the United States, ${ }^{99}$ but in the Soviet Union itself the number of psychiatric hospital beds did not follow the same pattern of decline. Instead the USSR added more beds, growing from 197000 in 1955 to 267,900 in 1970 and 312,600 in 1975. By 1990, when American deinstitutionalisation was complete, the Soviet Union boasted 349,800

93 'O merakh uluchsheniia psikhonevrologichskoi pomoshchi', 20 August 1954, GARF, f. a- 482, op. 49, d. 8347, 1. 113.

94 'O merakh uluchsheniia psikhonevrologichskoi pomoshchi', 20 August 1954, GARF, f. a- 482, op. 49, d. 8347, 1. 113 .

95 'Sprakva k protokolu no. 5 zasedanii kollegii MZ SSSR', 2 February 1956, GARF f. r-8009, op. 1, d. $1287,1$. 186.

96 'Klinicheskaia konferentsiia', op. cit. (note 21), 1. 51ob.

97 Albert Deutsch, The Shame of the States (New York: Harcourt, Brace and Company, 1948).

98 Shorter, op. cit. (note 2), 280. During this period, American psychiatrists became very interested in the USSR's non-hospital psychiatry system, and a series of articles appeared which attempted to use the Soviet model as a source of lessons about how to implement community mental health in the United States. Gary S. Belkin, 'Writing about Their Science: American Interest in Soviet Psychiatry during the Post-Stalin Cold War', Perspectives in Biology and Medicine, 43, 1 (Autumn 1999), 31-46.

${ }^{99}$ D.E. Melekhov (ed.), Sotsial'naia readaptatsiia psikhicheski bol'nykh (Moscow: Gos. NII psikhiatrii MZ RSFSR, 1965), 3. 
psychiatric beds. ${ }^{100}$ Writing in the 1980s, historian David Joravsky referred to this Soviet build-up of psychiatric hospitals as an 'ironic process', in which the USSR adopted an antiquated approach to the problems of modernity just as the rest of the world figured out a better, more sophisticated solution. ${ }^{101}$ While Soviet adherence to an old asylum paradigm may have played some role, the ideological underpinnings of the Soviet psychiatric system and its position within the centrally planned economy were more important. In the Soviet central-planning system, health officials evaluated quality and success using metrics like the number of available hospital beds and square metres per patient. Psychiatrists jockeyed with other medical disciplines to get a part of scarce budgetary resources. For Soviet psychiatrists to advocate a decrease in the number of psychiatric beds would have been almost unthinkable. However, the logic of the plan was not the only factor involved. Since the revolution, Soviet psychiatrists had built their professional ethos around the goal of reforming the old asylums, turning them into psychiatric hospitals that were treatmentoriented places of healing. This vision of modern psychiatry called for the creation of a network of 'psychoneurological dispensaries' that would work to foster mental health in the community and provide long-term supporting care for chronic patients. The plans announced by the USSR Ministry of Health in 1954, 1956 and 1960 all envisioned increasing the number of psychiatric hospitals and psychoneurological dispensaries in order to make this modernised system a reality.

The first neuropsychiatric dispensaries had been opened in Moscow in the 1920s. ${ }^{102}$ As with most early Soviet schemes for social transformation, this plan foundered on the realities of Soviet life: there were virtually no resources for health care in general, much less for preventative psychiatry; there were very few trained psychiatrists; the country was almost entirely rural; and the leadership of the country had no interest in allowing 'mental hygiene' experts to dictate working conditions to the factory managers and Party bosses responsible for carrying out the Five-Year Plans. Therefore, the early Soviet vision for a comprehensive neuropsychiatric system with neuropsychiatric dispensaries at its core failed to become a reality. ${ }^{103}$

Some neuropsychiatric dispensaries continued to function, however, and the ideal of a non-hospital psychiatry remained part of official rhetoric. In 1940, there were 56 dispensaries in the USSR; by 1955 that number had risen to 111, and by 1960 it was

100 'Godovye spetsializirovanie otchety MZ SSSR o rabote psikhonevrologicheskikh bol'nitsakh i dispanserov' [1955], RGAE f. 1562, op. 27, d. 165; Narodnoe khoziaistvo SSSR: Statistcheskii ezhegonik (Moscow: Gosudarstvennoe statisticheskoe izdatel'stvo, 1965, 1975, 1990).

101 Joravsky, op. cit. (note 11), 432-3.

102 L.M. Rozenshtein, 'Novye zadachi Sovetskoi psikhiatrii (o psikhogigiene i psikhoprofilaktike)', in A.I. Miskinov and L.A. Prozorov (eds), Vtoroe vserossiiskoe soveshchanie po voprosam psikhiatrii $i$ nevrologii (Moscow: Izd. San-Prosv. Otd. NKZ, 1924), 6-10; L.M. Rozenshtein, 'O nevro-psikhiatricheskoi dispanserizatsii', in A.I. Miskinov, L.A. Prozorov and L.M. Rozenshtein (eds), Sovetskaia meditsina v bor'be za zdorovye nervy (Samara: Izd. Ul'ianovskogo kombinata PPP, 1926), 20-37; L.M. Rozenshtein, 'O rekonstruktsii nevropsikhiatricheskoi pomoshchi’, Sovetskaia nevropatologiia, psikhiatriia i psikhogigiena, 1, 3-4 (1932), 63$77,136-8$.

103 Gregory Dufaud and Lara Rzesnitzek, 'Soviet Psychiatry through the Prism of Circulation: The Case of Outpatient Psychiatry in the Interwar Period', Kritika: Explorations in Russian and Eurasian History, 17, 4 (2016), 781-803; David Joravsky, 'The construction of the Stalinist psyche', in Sheila Fitzpatrick (ed.), Cultural Revolution in Russia, 1928-31 (Bloomington, IN: Indiana University Press, 1978), 105-28. 
157. (About half of these -82 - were in the RSFSR.) ${ }^{104}$ The system suffered from serious problems, as internal inspections and reports consistently revealed. Buildings were small and understaffed and often lacked resources to provide daytime workshops or supervision for patients. Large swathes of the rural Soviet Union had no access to psychoneurological dispensaries and had to rely on local polyclinics or general hospitals for psychiatric care. ${ }^{105}$ But despite their very serious shortcomings, the psychoneurological dispensaries provided an important complement to the system of psychiatric hospitals. The psychoneurological dispensaries enabled psychiatric hospitals to check patients out knowing that they would have continuing supportive therapy in the place where they lived. The psychoneurological dispensaries also took on limited but real functions as first-line psychiatric clinics in major Soviet cities, providing short-term in-patient treatment and observation, conducting examinations of mental competence for the military and for courts and providing such services as speech therapy. ${ }^{106}$

Aminazine did not change the fundamental nature of this system. Rather, it reinforced Soviet public health officials' belief in the fundamental soundness of the Soviet model of an integrated psychiatric network and returned dispensaries to the centre of attention as the crucial component that made the new psychopharmacological treatments actually work. Dispensaries were given responsibility for keeping track of patients who were on 'supporting therapy', sending 'social care nurses' to do home visits and providing the medicine itself. ${ }^{107}$ In early trials of 'supporting therapy', some patients relapsed because they started drinking while at home or because they stopped taking their medicine. ${ }^{108}$ These patients needed to visit a doctor regularly for medical examinations and laboratory tests, and they needed a nurse or social worker to check in on them at home. These providers needed to be trained to recognise signs of relapse into psychiatric disease as well as signs of medical complications like Parkinsonism, hyperkinesia, sleeplessness and liver dysfunction. Training courses needed to be held to make sure that personnel had this specialised knowledge. An early study (conducted once again by someone who worked under Snezhnevskii) found excellent results: with the help of Aminazine, patients were able to maintain the recoveries that had begun in psychiatric hospitals. In many patients the results had actually improved over time. Crucially, the author found that when symptoms began to recur, he was able to use Aminazine to prevent a full relapse without having to send the patient to a psychiatric hospital for in-patient treatment. ${ }^{109}$

104 'Otchet NKZ SSSR o seti, deiatel'nosti i kadrakh meditsinskikh uchrezhdenii SSSR' [1940], RGAE, f. 1562, op. 18, d. 203; 'Kolichestvo psikhonevrologicheskikh bol'nits', in E. Babaian, 'Spravka o sostoianii psikhonevrologicheskoi pomoshchii naseleniiu SSSR', 20 May 1961, GARF, f. r-8009, op. 1, d. 1411, 1. 103; 'Godovye spetsializirovanie otchety...', op. cit. (note 100).

${ }^{105}$ For a typical litany of the problems with the psychoneurological dispensary system, see 'Prikaz 140 MZ RSFSR, 'O sostoianii vnebol'nichnoi p/nev-oi pomoshchi v Rossiskoi federatsii i merakh po ee uluchsheniiu', $G A R F$, f. a-482, op. 49, d. 6605, 11. 199-204.

106 T.I. Gol'dovskaia and I.S. Iolovich, 'O razvitii dispansernoi psikhonevrologicheskoi pomoshchi v Rossiiskoi Federatsii', ZNiP, 60, 9 (1960), 1085-8.

107 'Polozhenie o podderzhivaiushei terapii aminazinom v usloviiakh dispanera', 15 May 1957, TsAGM, 533, op. 1, d. 59, 11. 3-4; L.L. Rokhlin and I.G. Ravkin (eds), Podderzhivaiushchaia terapiia neirolepticheskimi sredstvami bol'nykh shizofreniei: metodicheskie materialy (Moscow: Gos. nauchno-issledovatel'skii institut psikhiatrii, 1961), 4-13, 46-53.

${ }^{108}$ I.G. Ravkin and N.F. Samter, 'Osnovnye printsipy podderzhivaiushchei, profilakitcheskoi terapii pri shizofrenii', Zhurnal nevropatologii i psikhatrii im. S.S. Korsakova, 60, 9 (1960), 1204.

109 V.G. Levit, 'K voprosu ob organizatsii podderzhivaiushchei terapii neirolepticheskimi sredstvami', Zhurnal nevropatologii i psikhatrii im. S.S. Korsakova, 58, 5 (1958), 625-7. 
Aminazine became so central to the work of the neuropsychiatric dispensaries that psychiatrists began to note with alarm that older methods, such as labour therapy, were no longer being used. Speaking at a 1958 conference, one neuropsychiatric dispensary director said, 'It's a problem that we, possessing such a tool [as Aminazine], forget about our old, tested methods of treatment, which also strengthen remission and pre-empt the onset of decompensation. ...' Labour therapy in particular needed to be revived, he argued, but in combination with other, pre-Aminazine methods of supporting treatment: "with small doses of insulin, electrosleep, oxygen tents, with all methods available in ambulatory conditions'. ${ }^{110}$ Like the staff at psychiatric hospitals, workers at Soviet neuropsychiatric dispensaries seem to have abandoned more complicated, time-consuming activities and opted instead for the simple practice of giving patients Aminazine. In 1963, the Soviet government mandated that Aminazine be provided free of charge to all patients with schizophrenia who were undergoing supporting or preventative treatment. ${ }^{111}$ Aminazine was dispensed to patients primarily at the psychoneurological dispensaries, which now received special funds through local health departments. ${ }^{112}$ Psychiatrists credited the change with helping ensure that patients no longer tried to economise on their medicine, and thus avoided gaps in treatment. They also noted that it enabled them to give larger doses, closer to the dosages given in hospitals. ${ }^{113}$

Despite the construction of new psychiatric hospitals and the introduction of new drugs, the Soviet psychiatric system continued to suffer from chronic overcrowding. A 1961 report found that, if anything, the situation in 1960 was worse than it had been five years earlier. The problem was that much of the expansion had been achieved by crowding more patients into existing structures. A 1961 report acknowledged this, noting that ' 8000 10000 beds have been added each year, mainly by further crowding patients into existing institutions' ${ }^{114}$ The result was that most patients had only $0.5-1.5$ square metres of space, even though the official 'sanitary norm' was 7 square metres per patient. 'All the ancillary spaces (corridors, break rooms, cafeterias) are filled with patients,' a psychiatrist reported. 'Patients are often kept two to a bed, or on the floor.' Fights were a constant problem, and the number of serious injuries to staff had increased 'significantly' since $1950 .{ }^{115}$

These problems were discussed in the Collegium of the USSR Ministry of Health in May 1961. In their analysis of the problem, the participants saw the overcrowding of psychiatric hospitals as a problem of demand. Based on an internal analysis, they estimated that in-patient psychiatric treatment would be needed for 4-4.5 people per thousand each year, a figure which they noted very clearly 'corresponds to the number of psychiatric beds

${ }^{110}$ M.S. Kogan, in 'Stenogramma konferentsii Instituta psikhiatrii MZ SSSR po itogam nauchnoi raboty za 1957 god', 15 May 1958, GARF, f. r-9592, op. 1, d. 24, 1. 45.

${ }^{111}$ Free medication for outpatient psychiatric patients was mandated by the USSR Council of Ministers and implemented by USSR Ministry of Health decree \#317 (4 July 1963). See 'Otchet o vypolnenii plana raboty Gl. Upr. Lechebno-prof. pomoshchi MZ SSR za 1963', GARF, f. r-8009, op. 33, d. 976, 1. 13.

112 'Instruktsiia MZ SSSR o poriadke organizatsii i ucheta besplatnogo otpuska medikamentov pri ambulatornom lechenii nekotorykh kategorii bol'nykh', 8 August 1965, GARF, f. r-8009, op. 33, d. 1061, 11. 88-91ob.

113 'Ob'iasnitel'naia zapiska. . ', op. cit. (note 54), 11. 38-9.

114 Interestingly, the report also noted that: 'In recent years the organs of health protection have been given a large number of prisons and corrective labour camps, in which new psychoneurological hospitals and psychiatric colonies have quickly been organised.' In other words, GULAG buildings vacated by Khrushchev's amnesty of labour-camp prisoners were being repopulated with psychiatric patients. Babaian, op cit. (note 104), 1. 93.

115 Ibid., 11. 90-1. Nathan Kline described the beds in the psychiatric hospitals that he visited as 'a full 6 inches narrower than our own and, in many places, only 1 foot or so apart'. Nathan S. Kline, 'The Organization of Psychiatric Care and Psychiatric Research in the Union of Soviet Socialist Republics', Annals of The New York Academy of Sciences, 84 (April 1960), 169. 
provided for the population in the more developed capitalist countries: USA - 4.43/1 000; Canada - 4.22; Switzerland - 4.03'. The population of the USSR in 1961 was 216.1 million, and the USSR Ministry of Health estimated, therefore, that the country's real need was for ' $850-900000$ beds'. ${ }^{116}$ The lack of beds, their report claimed, meant that 'about 300000 patients who need immediate hospitalisation, including socially dangerous people', were instead going untreated, causing an increase in crime and making 'the life of a certain part of the population more difficult and lowering the productivity of their labour'. ${ }^{117}$ In a memorandum to the Council of Ministers, the USSR Ministry of Health proposed building enough new psychiatric hospitals by 1965 to bring the ratio up to 2 beds per 1000 population, or 432000 beds in total, and to guarantee a neuropsychiatric dispensary for every town with over 50000 people. ${ }^{118}$

This 1961 meeting clearly articulated a dedication to maintaining and expanding the early Soviet model for Soviet psychiatric medicine, a model in which a large network of therapeutic institutions worked hand-in-hand with community-based dispensaries. The actual number of psychiatric beds in the Soviet Union never came close to reaching the proposed target of 900000 , but construction was nonetheless significant: by 1965 the number of psychiatric beds had increased from 162200 to $215500 .{ }^{119}$ This enabled psychiatric hospitals to cope both with population increase and with the accumulation of chronic patients, while attempting to check new patients out as quickly as possible. In 1963, a psychiatric hospital director in Moscow explained that to free up space in her hospital she was 'shortening examination periods, beginning treatment earlier and transferring [patients] to ambulatory supporting therapy'. ${ }^{120}$ What Aminazine helped facilitate in the Soviet Union, then, seems to have been a system in which psychiatric hospitals used Aminazine to move patients out of the door and into the jurisdiction of neuropsychiatric dispensaries. Publicly, Soviet psychiatrists claimed that this demonstrated the superiority of Soviet socialism. Privately, though, they were unsure. 'I am afraid,' the USSR's head psychiatrist admitted, 'that here very few remain in hospitals and we know why it's very few: because we check them out.' To which a colleague responded: 'We kick them out.' 121

\section{Conclusion}

By the 1960s, Soviet psychiatrists had become accustomed to using psychopharmacological treatments in everyday practice, and Soviet citizens had come to expect that drugs like Aminazine would be provided free of charge through psychoneurological dispensaries. In 1962, the USSR Ministry of Health began to revise its standards for staffing and training at psychiatric facilities, acknowledging that in recent years the structure and function of psychoneurological institutions have changed significantly.... [due to] the

\footnotetext{
116 Babaian, op. cit. (note 104), 11. 95, 99.

117 Ibid., 1. 92.

118 Ibid., 1. 114.

119 Narodnoe khoziaistvo SSSR: statistcheskii ezhegonik (Moscow: Gosudarstvennoe statisticheskoe izdatel'stvo, 1965), 750.

120 'Svedeniia dlia raikoma KPSS Kuib. R-na po kiln. p/nev b-tse \#4 im. Gannushkina', TsAGM, f. 533, op. 1, d. $81,1.9$.

121 'Stenogramma zasedaniia uchenogo soveta instituta psikhiatrii MZ SSSR', 21 March 1956, GARF, f. r-9592, op. 1, d. 21, 1. $15 \mathrm{ob}$.
} 
wide spread use of psychopharmaceuticals'. ${ }^{122}$ Treatments that had been common ten years earlier, like insulin shock therapy and sleep therapy, now seemed anachronistic. Like their colleagues in the West, Soviet psychiatrists had begun to narrate the history of their profession as a natural progression toward the psychopharmacological revolution. A brochure for laymen written in 1965 made this explicit. 'Even at the beginning of this century,' the author wrote, 'the treatment of psychoses remained ineffective. . . now new drugs are used on psychiatric wards, drugs which have little effect on other organs of the human body, but which normalise the mental condition of patients. These medicines, referred to as psychopharmaceuticals because of their effects, which primarily act on the psyche, are the achievement of the last decade. ${ }^{123}$ Psychopharmacology had become emblematic of Soviet psychiatry's status as a scientific medical discipline. Psychiatrists like Andrei Snezhnevskii used the new psychopharmacology to distance themselves from their Stalin-era dogmatism. They were able to drape themselves in the trappings of reform and scientific progress while maintaining institutional control of the Soviet psychiatric establishment. The clinical psychiatry that emerged during the Thaw as a result of this process remained in place into the 1980 s.

122 'Vypolnenie plana raboty po upravleniiu za 1962 god po gruppe psikhonevrologii', GARF, f. r-8009, op. 33, d. $946,1.23$.

123 V.I. Butorin, Chto nado znat' o nervno-psikhicheskikh zabolevaniiakh (Moscow: Meditsina, 1965), 28. 